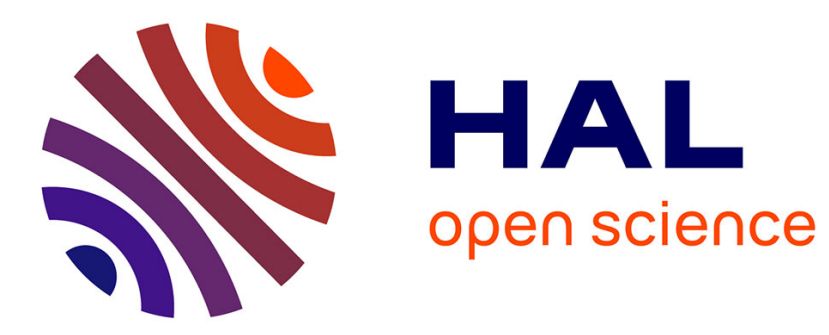

\title{
Seasonal distribution of sorghum midge (Contarinia sorghicola Coq.) and its hymenopterous parasites in Senegal \\ Ruparao Gahukar
}

\section{- To cite this version:}

Ruparao Gahukar. Seasonal distribution of sorghum midge (Contarinia sorghicola Coq.) and its hymenopterous parasites in Senegal. Agronomie, 1984, 4 (4), pp.393-397. hal-00884650

\section{HAL Id: hal-00884650 \\ https://hal.science/hal-00884650}

Submitted on 1 Jan 1984

HAL is a multi-disciplinary open access archive for the deposit and dissemination of scientific research documents, whether they are published or not. The documents may come from teaching and research institutions in France or abroad, or from public or private research centers.
L'archive ouverte pluridisciplinaire HAL, est destinée au dépôt et à la diffusion de documents scientifiques de niveau recherche, publiés ou non, émanant des établissements d'enseignement et de recherche français ou étrangers, des laboratoires publics ou privés. 


\title{
Seasonal distribution of sorghum midge (Contarinia sor- ghicola Coq.) and its hymenopterous parasites in Senegal
}

\author{
Ruparao GAHUKAR (1) \\ International Crops Research Institute for the Semi-Arid Tropics (ICRISAT) \\ Cooperative Programme, CNRA, B.P. 5I, Bambey, Senegal
}

\begin{abstract}
The population distribution of the sorghum midge, Contarinia sorghicola Coq., and its hymenopterous parasites, Tetrastichus diplosidis Crawford, Eupelmus popa Girault, E. australicus Girault, and Aprostocetus sp., was studied during the 1978 and 1979 crop seasons at Bambey, Senegal. The population ratio obtained in laboratory rearing ranged from 1 midge for 3 parasites to 1 parasite for 41 midges depending upon the period and sorghum cultivar ('Congossane', 'CE 90', '51-69'). T. diplosidis was a major parasite which proved to be most active against sorghum midge.
\end{abstract}

Additional key words : Climatic factor, phenological coincidence, population dynamics, parasite complex, cultivars.

\begin{abstract}
Distribution saisonnière de la cécidomyie du sorgho (Contarinia sorghicola Coq.) et de ses parasites hyménoptères, au Sénégal.

La distribution de la population de la cécidomyie, Contarinia sorghicola Coq., et de ses parasites hyménoptères, notamment, Tetrastichus diplosidis Crawford, Eupelmus popa Girault, E. australicus Girault et Aprostocetus sp., a été étudiée pendant les saisons pluviales 1978 et 1979 à Bambey, Sénégal. La proportion d'insectes obtenus dans les élevages au laboratoire était de l'ordre de 1 cécidomyie pour 3 parasites ou de 1 parasite pour 41 cécidomyies en fonction de la période et des cultivars ("Congossane », "CE 90 ", " 51-69 »). T. diplosidis a été le parasite majeur qui s'est montré le plus actif contre la cécidomyie.
\end{abstract}

Mots clés additionnels : Facteur climatique, coincidences phénologiques, dynamique de population, complexe parasitaire, cultivars.

\section{INTRODUCTION}

The sorghum midge, Contarinia sorghicola Coq. (Cecidomyiidae, Diptera) is distributed throughout the sorghum growing areas in the world and is probably first in importance of all the sorghum insect pests (YOUNG \& TEETES, 1977). In West Africa, midge damage to grain sorghum has been reported from Nigeria (HARRIS, 1961), Ghana (BOWDEN, 1965), Senegal (CouTIN, 1970) and Upper Volta, Mali, Niger and Cameroun (COUTIN, 1969). The pest has received more attention in recent years in Senegal since sorghums of different maturity period are grown with a wide range of planting dates on research stations.

(') Present address : FAO Entomologist, CILSS IPM Project, IsRA, B.P. 199, Kaolack, Senegal.
Similarly, local sorghums sown after second or third rains are generally attacked (GAHUKAR, 1980).

The distribution of sorghum midge is influenced by pest multivoltinism, natural enemies, larval diapause, climatic conditions and availability of flowering heads during the crop season. These factors play an important role in pest management. In Senegal, some insecticides have been experimented to reduce the pest population (COUTIN, 1970) and little attention has been given to native parasite complexes. CouTIN (1970) reported 2 hymenopterous parasites (Tetrastichus diplosidis Crawford and Eupelmus popa Girault). Recently, we noted the presence of 2 additional parasites, viz., Aprostocetus sp. and Eupelmus australicus Girault (GAHUKAR, 1981). The present study was undertaken to know the seasonal abundance and distribution of sorghum midge and the status of native midge parasites. 


\section{MATERIAL AND METHODS}

At Bambey research station (CNRA), 2 local sorghum cultivars ('Congossane' and ' $\mathrm{CE} 90$ ') were sown at weekly intervals from 21 July to 9 September in 1978 (8 sowings) and from 23 June to 21 September in 1979 ( 14 sowings). One additional local cultivar ' 51 69' was sown from 28 July to 21 September in 1979 (9 sowings). ' $\mathrm{CE} 90$ ' and ' $51-69$ ' are the improved high yielding cultivars of 90 and 110 days maturity period respectively, whereas 'Congossane' is a long cycle (130 days) traditional cultivar.

The experiment was laid out in a split plot design with 3 replications. Sowing dates were main plots and cultivars were the sub-plots. Each sub-plot was of 5 rows of 5 meters and $80 \mathrm{~cm}$ apart. Recommended cultural practices were followed and plots were irrigated whenever necessary. At initial flowering, 30 heads of the same flowering period were tagged at random in each sub-plot. Ten days later, 20 heads in 4 replications were excised at random and brought in laboratory and were placed individually for rearing in the plastic vials $(15 \mathrm{~cm}$ diameter). This technique of midge rearing is analogue to that of COUTIN (1970). The midges and parasites emerging from infested heads were collected daily till their emergence was completed.

\section{RESULTS}

At the beginning of the crop season, 'CE 90' flowered in 55-60 days and 'Congossane' and '51-69' took about 80-90 days, but later in the season, all 3 cultivars flowered comparatively earlier. The continuous availability of flowering heads provided favourable conditions for the development of the naturally occurring midge population. In the laboratory, midges emerged from infested heads over a 1-2 week period and parasites were collected 1-2 days after the majority of midges had completed their emergence. Midge emergence was noted as early as the second or third day after being placed in vials. Four hymenopterous parasites were recorded from midge-infested heads, viz., $T$. diplosidis and Aprostocetus sp. (family Eulophidae) and E. popa and E. australicus (family Eupelmidae).

1978: The sorghum midge and its parasites were absent in the plots of ' $\mathrm{CE} 90$ ' sown on 21 July. The midge has built up its population during later period of September resulting in a peak with 592 midges $/ 20$ heads sampled on 17 October (fig. 1). The parasites followed the same pattern of fluctuation as that of their host. Following this there was a gradual increase up to 52 parasites $/ 20$ heads. However, highest population ratio of 1 midge : 6 parasites was noted on heads flowering during last week of October.

The early flowering heads of 'Congossane' facilitated the transfer of pest and parasites from ' $\mathrm{CE} \mathrm{90'}$ plots. Midge attacked 'Congossane' heads flowering from 25 October onwards. Peak incidence of both midges and parasites was recorded during second week of November (fig. 1). Parasites outnumbered the midges from November but were effective in checking the pest only at the end of the crop season when a

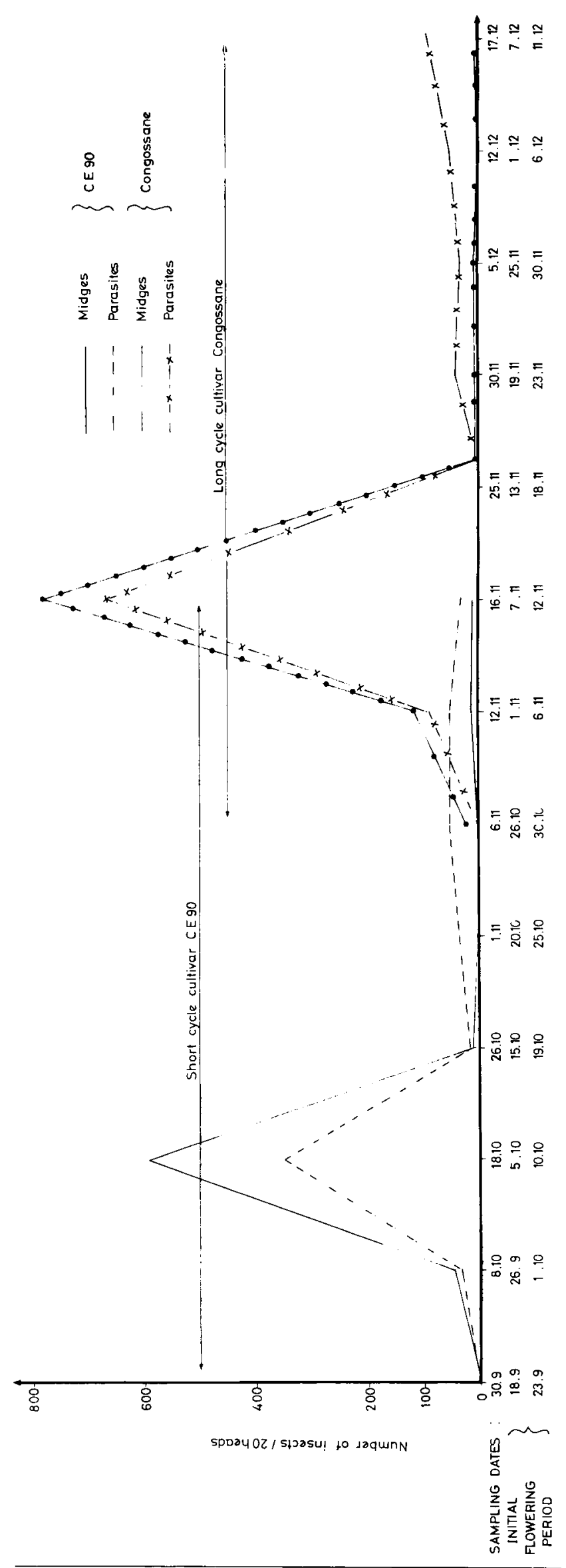

Figure 1

Number of sorghum midge and its parasites on 2 sorghum cultivars at Bambey 1978.

Nombre de cécidomyies du sorgho et de parasites sur 2 cultivars de sorgho, à Bambey en 1978. 
population ratio of 1 midge : 22 parasites was observed. Thus, the 2 peaks of midge population were synchronized with that of its parasites recorded during second week of October and November.

1979: Sorghum midge was present throughout the crop season. The short cycle cultivar 'CE 90' flowered as early as 22 August. Thus, the population increased gradually and peak incidence was noted during last week of September and first week of October (12 47012798 midges/20 heads, fig. 2). Although parasites were present from the end of September to the beginning of November, they were not numerous enough to control the pest (ratio of 1 parasite : 41 midges). Among 646 parasites recovered from 'CE 90' heads, 477 were $T$. diplosidis (73.08\%), 14 E. popa and 155 Aprostocetus and E. australicus.

The first sowing on 23 June of 'Congossane' started flowering on 20 September when both midge and parasites were present in the field. The highest population ratio of midge to parasites, $1: 54$ in favour of parasites, was noted on heads which started flowering in mid-October. Thereafter, midge population increased faster than that of parasites and a peak was noted on heads sampled on 19 November (444 midges/20 heads). Of 1378 parasites collected from 'Congossane' heads, 1100 were $T$. diplosidis $(79.8 \%), 14 E$. popa and 14 were other parasites.

In the plots of 51-69, a low pest population was present in October (fig. 2), but increased slowly in mid-November (1 664 midges $/ 20$ heads). Only few parasites were active during the second fortnight of October (ratio of 1 midge : 2 parasites). $T$. diplosidis was the major parasite representing $83 \%$ of total population, E. popa was absent and other parasites were rare.

\section{DISCUSSION AND CONCLUSION}

GARG \& TALEY (1978) studied the population fluctuations of sorghum midge and its parasites (Tetrastichus sp.) by counting them on flowering heads. In fact, these insects stay very little on a single head and move from one head to another frequently, which complicates the recording. Moreover, in the absence of natural enemies, midges are continuously present in the field and the active population is renewed daily where flowering heads are available.
Laboratory rearing gave satisfactory results to study the population distribution.

There was a synchronization of seasonal distribution and comparative frequency of occurrence between midge and parasite populations in 1978. Pest abundance was noted at the beginning of the 1979 season due to absence of natural enemies. Thereafter parasites were active in the plots of all 3 cultivars. Some parasites might have migrated from neighbouring millet fields as Tetrastichus is also an important parasite of millet midge, Geromyia penniseti (Felt) in Senegal (COUTIN \& HARRIS, 1968). The development of these parasites should be favoured very early in the season which seems to be problematical in present peasant farming conditions. It may also happen that whole pest population is not destroyed by parasites (as in case of ' 51-69' and 'Congossane' in 1979) and some portion of larval population undergoes diapause. Pest number is therefore naturally checked. But the diapaused larvae remain in spikelets and survive hot dry weather to attack the next season's crop. In Senegal, improved cultivars may be released in the near future for farmers' use. The short-cycle sorghums would certainly favour midge activity and serious attack may occur on late traditional cultivars. It is therefore suggested that only one cultivar or cultivars of the same maturity cycle should be grown in the region.

COUTIN (1970) reported that $E$. popa was a major parasite in Senegal during 1966-69 and the parasitism level was only 2.3 of $4.3 \%$. In the present study, T. diplosidis appeared constantly in the field and accounted for $73-83 \%$ of the total parasite population in 1979. This finding disagrees with the earlier report. Thus any predominance of $E$. popa that might have occurred during earlier years has now been regained by $T$. diplosidis which proved to be an active parasite. Therefore, the possibility of utilizing this parasite in midge management should be explored in future sorghum improvement programmes.

Received March 16, 1983 Accepted December 28, 1983.

\section{ACKNOWLEDGEMENTS}

I am thankful to the taxonomists of British Museum (NH), London (U.K.), for the identification of parasites and Dr. CouriN (I.N.R.A., Versailles, France) for his valuable suggestions on the manuscript. 


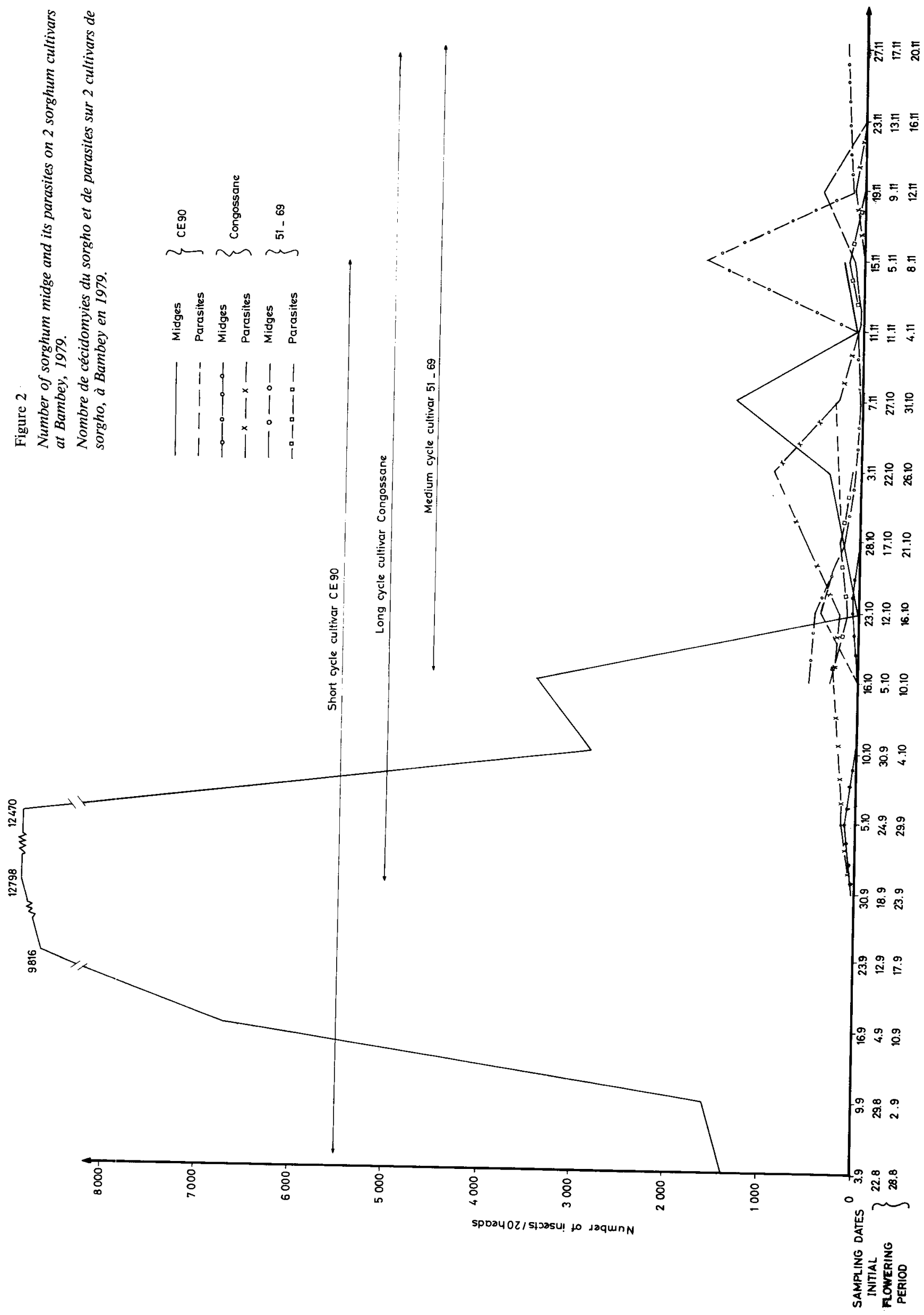




\section{REFERENCES}

Bowden J., 1965. Sorghum midge, Contarinia sorghicola (Coq.) and other causes of grain sorghum loss in Ghana. Bull. Entomol. Res., 56, 169-189.

Coutin R., 1969. Récente extension mondiale et présence de la cécidomyie du sorgho (Contarinia sorghicola Coq. 1898) en France méridionale. Bull. Soc. Entomol. Fr., 74, 13-20.

Coutin R., 1970. Biologie de la cécidomyie du sorgho (Contarinia sorghicola Coq.) et lutte chimique. Phytiatr. Phytopharm., 19, 6583.

Coutin R., Harris K. M., 1968. The taxonomy, distribution, biology and economic importance of the millet grain midge, Geromyia penniseti (Felt), gen. n., comb. n. (Dipt., Cecidomyiidae). Bull. Entomol. Res., 59, 259-273.
Gahukar R. T., 1980. Inventaire des insectes nuisibles du sorgho au Sénégal. CNRA, Bambey, Senegal, Cyclost., 23 p.

Gahukar R. T., 1981. Rapport d'activité de l'année 1980. Programme d'entomologie du sorgho de l'ICRISAT. CNRA, Bambey, Cyclost., 33 p.

Garg D. O., Taley Y. M., 1978. Note on trends in population fluctuation of Contarinia sorghicola Coq. and Tetrastichus sp., its parasite, on sorghum during 1975-76. Indian J. Agric. Sci., 48, 51-53.

Harris K. M., 1961. The sorghum midge, Contarinia sorghicola (Coq.) in Nigeria. Bull. Entomol. Res., 52, 129-146.

Young W. R., Teetes G. L., 1977. Sorghum entomology. Annu. Rev. Entomol., 22, 193-218. 